\title{
Usytuowanie fonologicznych cech dystynktywnych w strukturze poszczególnych typów cech głosowych
}

\author{
The Location of Phonological Distinctive Features \\ in the Structure of Individual Types of Voice Features
}

\author{
Włodzimierz Lapis \\ Instytut Językoznawstwa, Uniwersytet im. Adama Mickiewicza \\ al. Niepodległości 4, 61-874 Poznań \\ lapisweamu.edu.pl \\ Ważne sa nie rzeczy, lecz stosunki między nimi \\ E. T. Bell ${ }^{1}$
}

\begin{abstract}
Based on the analysis of entries from Polański 1999, the present work - as its title indicates explores "the location of phonological distinctive features in the structure of individual types of voice features". The exploration of this topic will enable us to properly comprehend the notion of 'distinctiveness' (primarily in linguistics, but - through natural expansion - also in other domains of sciences). We will address such questions as: what it is (and what it is not), how to understand it, what kinds of distinctiveness exist, and which of its aspects we might deal with.
\end{abstract}

\section{Metodologia pracy}

$\mathrm{Na}$ gruncie jezzykoznawstwa, zagadnienie cech dystynktywnych najpełniej jest opisane i najczęściej odnoszone $\mathrm{w}$ odniesieniu do fonologii. W oparciu o hasła z Polański 1999 (cechy fonologiczne - s. 84, cecha niedystynktywna - s. 82, relewancja - s. 493, allofons. 38, fonologiczne cechy ekspresywne (emfatyczne) - s. 173, fonologiczne cechy konfiguracyjne - s. 173, fonologiczne cechy dystynktywne (diakrytyczne) - ss. 171-172, cecha korelacyjna - s. 82, korelacja - s. 318, fonologia (fonemika, fonematyka) - ss. 159162), możemy pokusić się o określenie klasyfikacji cech głosowych, a wśród nich fonologicznych cech dystynktywnych.

Dokonamy tego po kolei analizując wyżej zasygnalizowane hasła i sprawdzając, jak rozbudowują (czy też modyfikują) one naszą dotychczasową wiedzę na temat dystynktywności. Badania na bieżąco będą obrazowane stosownymi schematami, a pod

${ }^{1}$ Za Jakobson 1989, s. 226 
koniec pracy podane zostaną wynikające $\mathrm{z}$ niej wnioski. Analizując powyższe hasła będziemy abstrahować od ukazywania różnych podejść w poszczególnych systemach językowych (szkołach). biuletynem poświęconym językoznawstwu i naukom pokrewnym.

\section{Analiza hasel słownikowych}

Zacznijmy naszą pracę od podania definicji cech fonologicznych:

Cechy fonologiczne. Właściwości fonetyczne sygnałów mowy obarczone w danym jęz. określoną funkcją semiotyczną, istotne z punktu widzenia porozumiewania się za pomocą tego jęz. jako skonwencjonalizowane sygnały przekazywania informacji. Ze względu na funkcje (rodzaj przekazywanych informacji jęz.) wyróżnia się 3 typy f. c.: f. c. dystynktywne, f. c. konfiguracyjne i f. c. ekspresywne. ${ }^{2}$

W oparciu o tę definicje otrzymujemy następujący schemat usytuowania cech dystynktywnych:

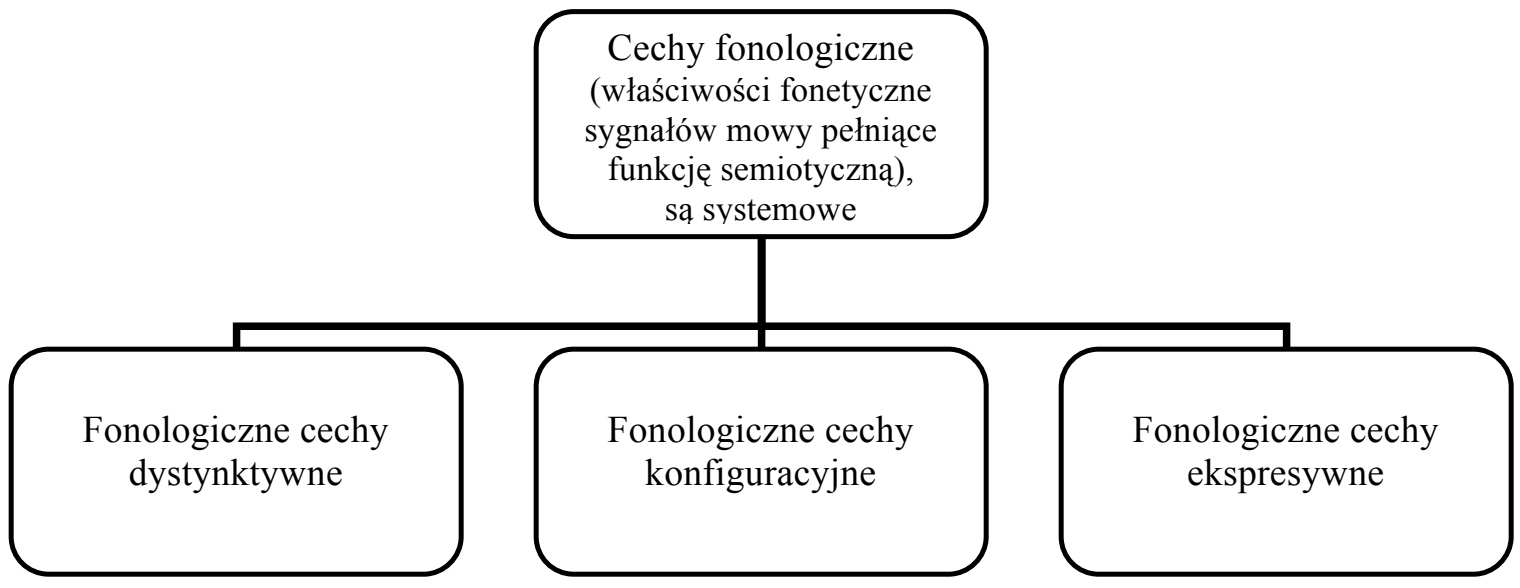

Schemat 1

Przypatrzmy się obecnie pojęciu cecha niedystynktywna:

Cecha niedystynktywna. Cecha głosowa, która w danym jęz. nie pełni funkcji fonologicznej - określana jest także jako c. niefonologiczna. Należą tu z jednaj strony cechy będące wynikiem wpływu sąsiedztwa dźwiękowego (np. dziąsłowość d w wyrazie drzewo), z drugiej strony cechy charakteryzujące warianty fakultatywne, czyli allofony.

$\mathrm{Z}$ jednej strony ustawia ona $\mathrm{w}$ opozycji do cech fonologicznych cechy niedystynktywne (jako niefonologiczne), razem nazywając je cechami głosowymi. $Z$ drugiej zaś strony specyfikuje rodzaje cech niedystynktywnych (jako cechy będące wynikiem wpływu sąsiedztwa dźwiękowego czy też charakteryzujące warianty fakultatywne, czyli alofony). W oparciu o te rozważania możemy zmodyfikować poprzedni schemat na następującego:

\footnotetext{
${ }^{2}$ Polański 1999, s. 84

${ }^{3}$ Polański 1999, s. 82
} 


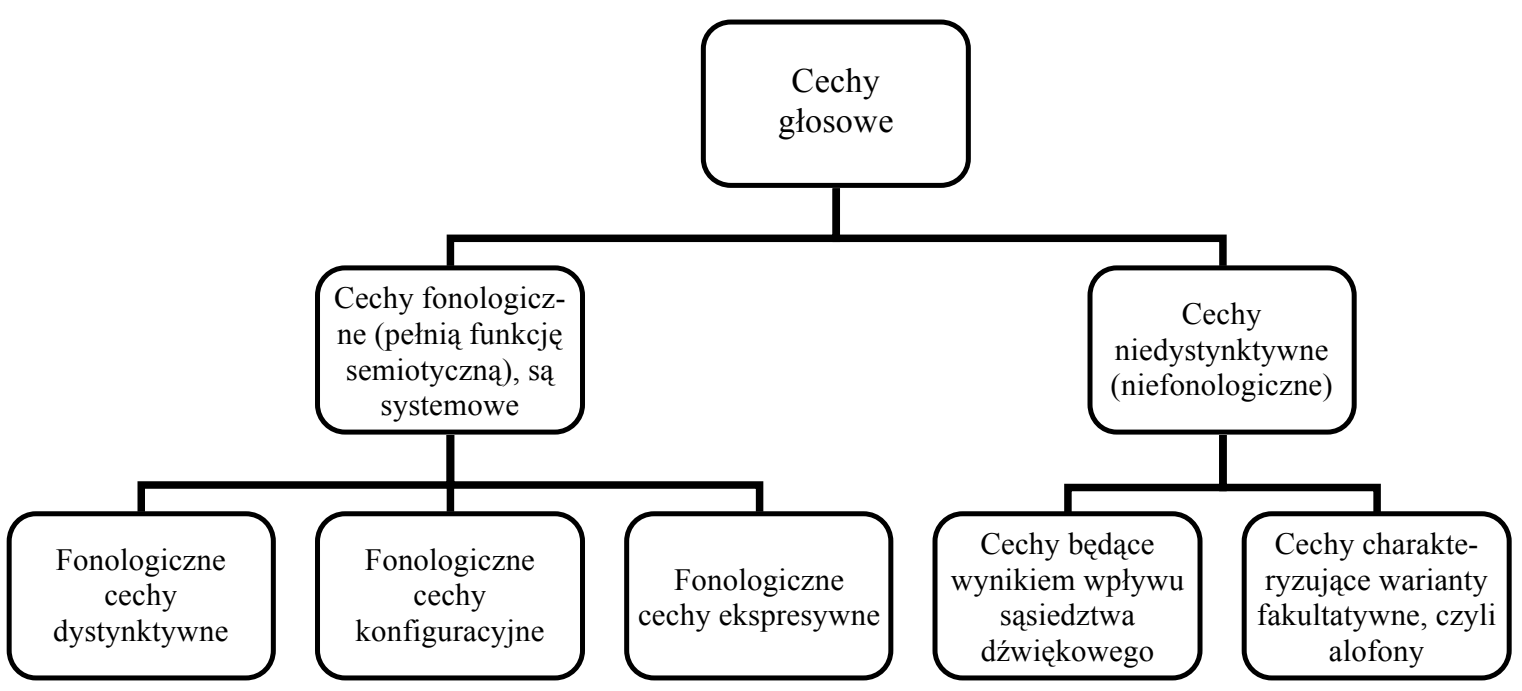

Schemat 2

Dodatkowe uszeregowanie cech fonologicznych oraz dopowiedzenie i uporządkowanie w zakresie cech niedystynktywnych daje nam następująca definicji:

Relewancja. Jedna z zasad językoznawstwa strukturalistycznego, postulująca wyodrębnienie $\mathrm{w}$ opisie jęz. elementów i cech istotnych, tzn. cech pełniących określone funkcje w komunikacji jęz., od elementów i cech nieistotnych dla komunikatywnej funkcji jęz. Np. w zakresie systemu dźwiękowego do relewantnych należą cechy pełniące funkcję dystynktywną (...) czy delimitacyjną (zob. Fonologiczne cechy konfiguracyjne), natomiast do nierelewantnych należą cechy, które składają się na różnice między wariantami pozycyjnymi czy fakultatywnymi (zob. Alofon).

Definicja ta:

Ang. relevant 'istotny, trafny', ze śrdwłac. relevans ${ }^{4}$

$>$ określa relewantność jako istotność (w danym zakresie),

$>$ grupuje jako relewantne fonologiczne cechy dystynktywne i konfiguracyjne,

$>$ jako nierelewantne ustanawia te cechy, które dotychczas określaliśmy jako niedystynktywne,

$>$ przy czym innymi słowy określa ,cechy będące wynikiem wpływu sąsiedztwa dźwiękowego",

$>$ a nadto - dla cech konfiguracyjnych wprowadza nazwę synonimiczną - cechy delimitacyjne.

Rozbudowę dotychczasowego schematu przedstawiono poniżej:

${ }^{4}$ Polański 1999, s. 493 


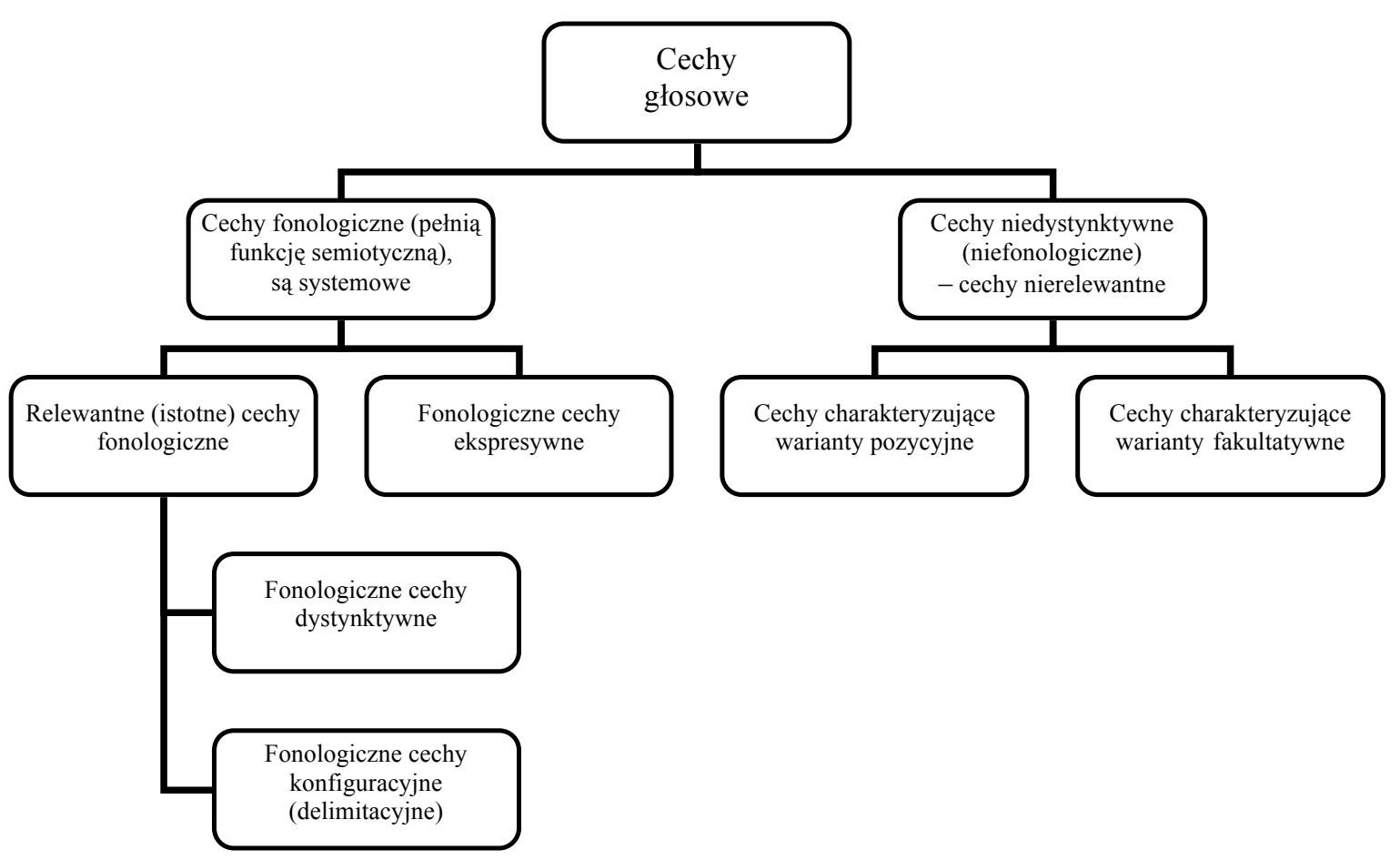

Schemat 3

Bardziej szczegółowej charakterystyki poszczególnych typów cech niedystynktywnych możemy dokonać $\mathrm{w}$ oparciu o poniższą definicję (co obrazuje zamieszczony pod nią schemat).

Allofon. Głoska będąca realizacją (manifestacją) fonemu, wariant fon e mu . Każdy fonem jest reprezentowany przez pewien określony, sobie tylko właściwy zbiór a. Wystapienie w wypowiedzeniu konkretnego a. w funkcji reprezentacji (realizacji) danego fonemu może być albo zdeterminowane przez kontekst fonologiczny (..) - są to warianty kombinatoryczne, nazywane też pozycyjnymi, tego fonemu, albo też może być niezależne od kontekstu. W ostatnim wypadku mamy do czynienia z fakultatywnymi wariantami fonemu (...). Nie mogą być realizacjami dwu różnych fonemów te głoski, między którymi różnice fonetyczne nie są dystynktywne. (...) Przede wszystkim dotyczy to głosek, których wzajemna substytucja (zastapienie jednej przez drugą) nie pociaga za sobą żadnych różnic znaczeniowych (...) $\mathrm{Z}$ reguły wybór jednego $\mathrm{z}$ fakultatywnych wariantów jest zdeterminowany stylistycznie (...), geograficznie (...) bądź też właściwościami jęz. osobniczego. (...)

Grec. állos 'inny, różny', rdzeń fon- (np. phoné 'dźwięk') ${ }^{5}$

\footnotetext{
${ }^{5}$ Polański 1999, s. 38
} 


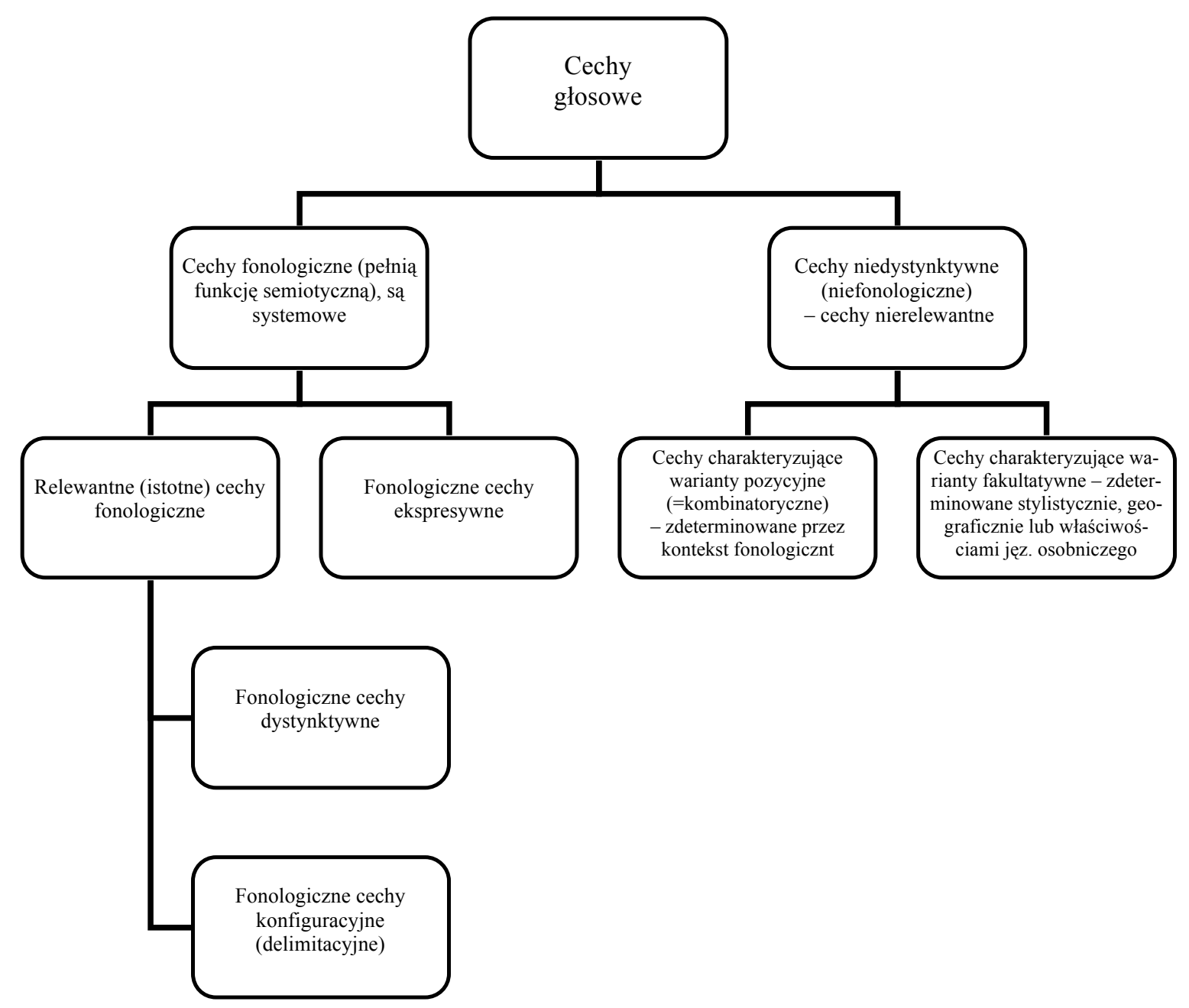

Schemat 4

Poniżej przyjrzyjmy się już tylko poszczególnym typom cech fonologicznych cechom ekspresywnym, dystynktywnym i delimitacyjnym.

Zacznijmy od poniższej definicji fonologicznych cech ekspresywnych:

Fonologiczne cechy ekspresywne (emfatyczne). Skonwencjonalizowane, charakterystyczne dla danego jęz. sygnały fonetyczne, służące do przekazywania informacji o emocjonalnym ustosunkowaniu osoby mówiącej do własnej wypowiedzi. W pol. np. funkcję tego typu sygnałów spełniać może iloczas (ekspresywne wydłużenie) samogłosek, wydłużenie i wzmocnienie spółgłosek, zwarcie krtani po wygłosowej samogłosce niektórych wyrazów. Zarówno f. c. e., jak i f. c. dystynktywne służą w jęz. do sygnalizowania różnic znaczeniowych między wypowiedzeniami. Jednakże podczas gdy w wypadku f. c. e. istnieje stały związek między właściwością fonetyczną (np. długość spółgłoski) a danym znaczeniem (ekspresywnym), to w wypadku f. c. dystynktywnych takiego zwiazku nie ma. ${ }^{6}$

Definicja ta wprowadza synonimiczne określenie fonologicznych cech ekspresywnych - nazywając je echami „emfatycznymi”, charakteryzuje je (jako „emocjonalne”) oraz porównuje z cechami dystynktywnymi, co oddane zostało na poniższym schemacie:

${ }^{6}$ Polański 1999, s. 173 


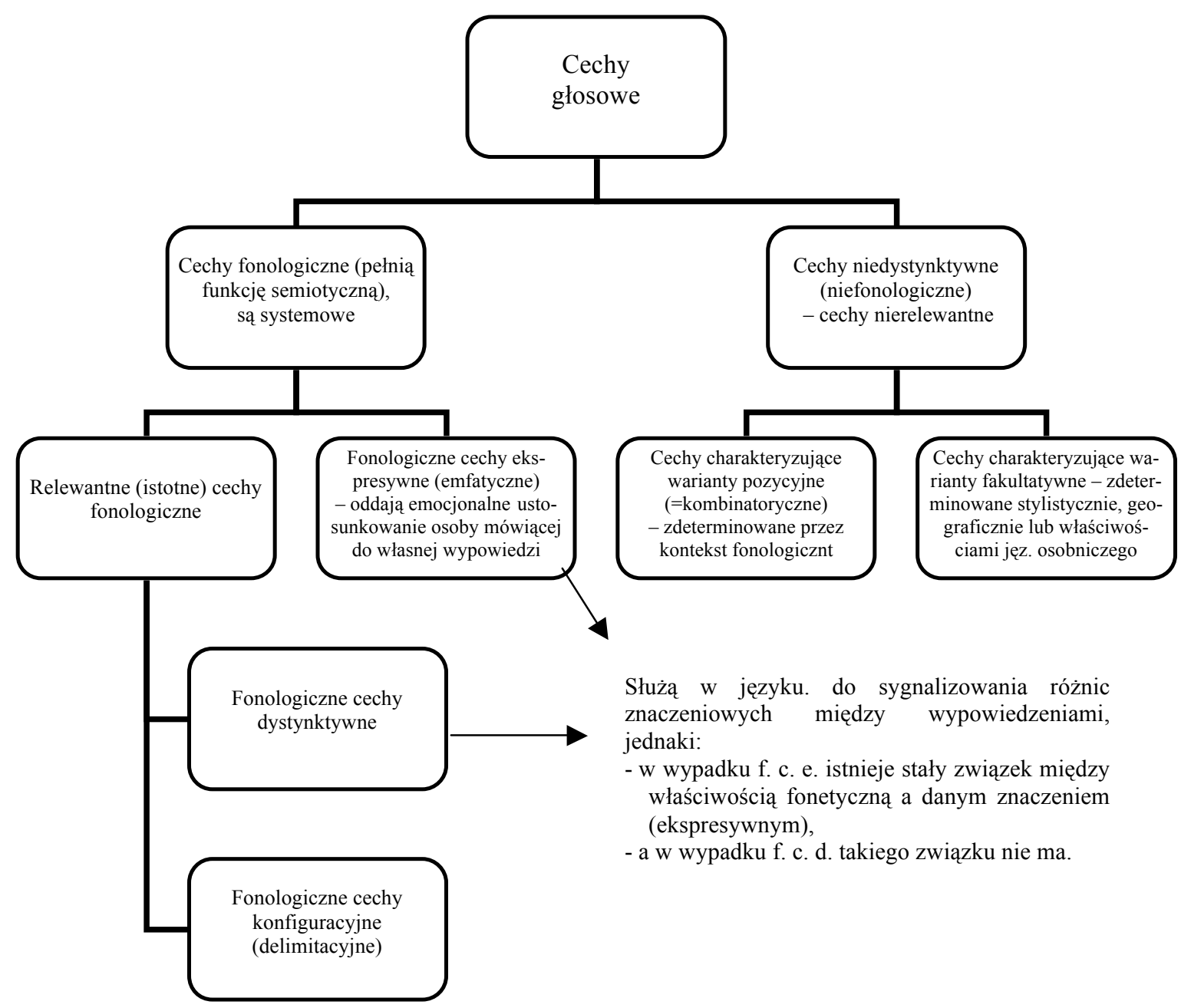

Schemat 5

Obecnie rozpatrzymy definicję fonologicznych cech konfiguracyjnych.

Fonologiczne cechy konfiguracyjne. Charakterystyczne dla danego jęz. skonwencjonalizowane fonetyczne sygnały rozczłonkowania tekstu na elementy składowe: zdania, wyrazy tekstowe, morfemy. F. c. k. mogą albo tylko sygnalizować liczę jednostek danego typu w tekście (bez wskazywania granic między tymi jednostkami) - są to f. c. kulminacyjne [akcent ruchomy - WL], albo też wskazują na granice między elementami tekstu-f. c. demarkacyjne (rozgraniczające) [akcent stały-WL].

Łac. configuratio 'uksztattowanie, układ' ${ }^{7}$

Stwierdza ona, że :

$>$ cechy te rozczłonkowują tekst,

$>$ jeśli tylko sygnalizują jednostki w tekście, to nazywamy je fonologicznymi cechami kulminacyjnymi, a gdy dodatkowo sygnalizują ich granice - to nazywamy je fonologicznymi cechami demarkacyjnymi (rozgraniczającymi)

W wyniku tych rozważań otrzymujemy następujący schemat:

${ }^{7}$ Polański 1999, s. 173 


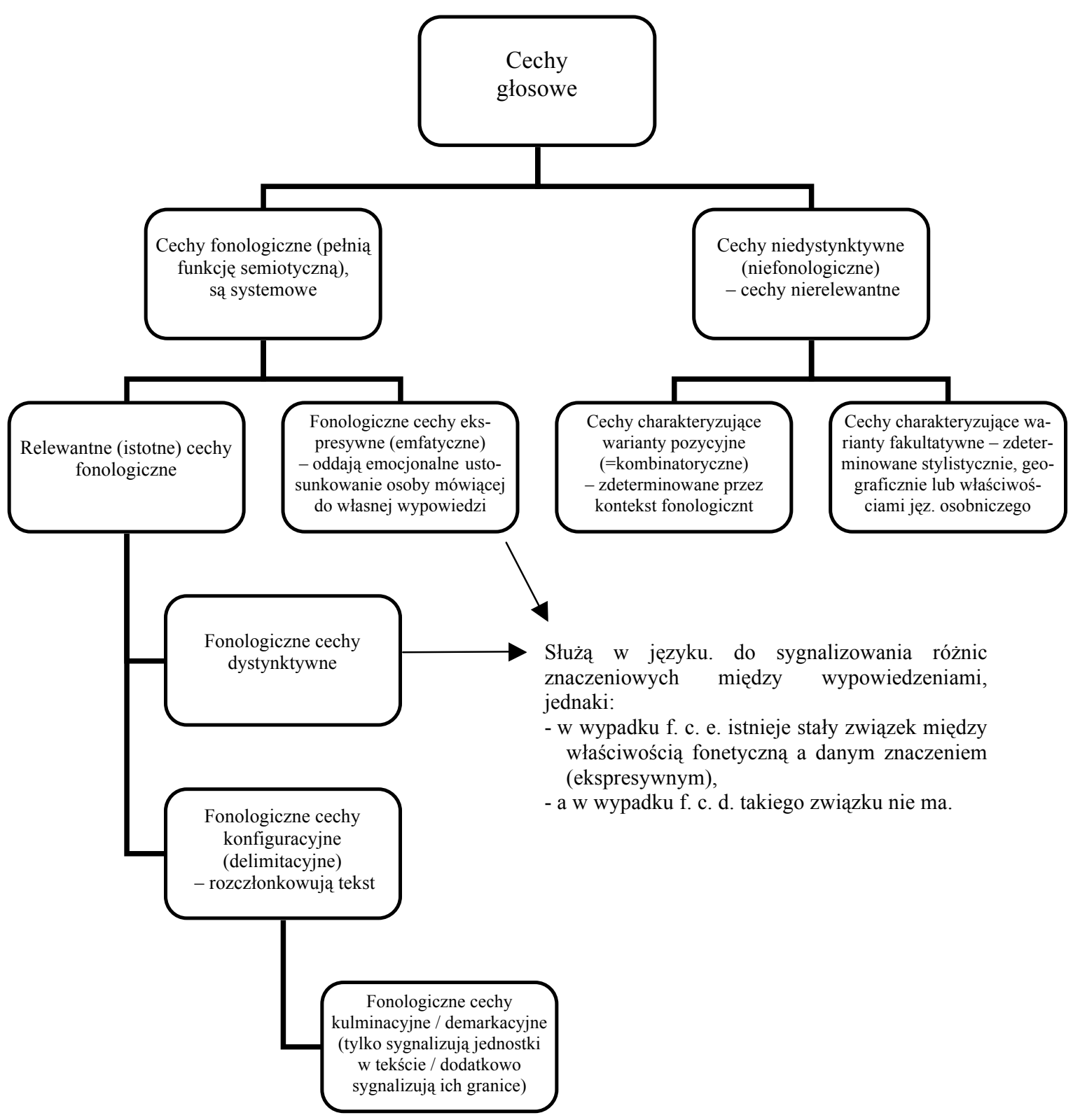

Schemat 6

$\mathrm{Na}$ zakończenie przytoczmy pięć definicji tyczących się fonologicznych cech dystynktywnych:

1. Fonologiczne cechy dystynktywne (diakrytyczne). Właściwości fonetyczne spetniaja $w$ danym jęz. funkcję odróżniajaca, tzn. wykorzystywane $w$ nim jako sygnały pozwalające na rozróżnienie znaków jęz. (...) Istnieja 2 typy $f$. c. d.: a) cechy inherentne, definiowalne bez odwołania sie do pojęcia sylaby (np. nosowość, dźwięczność, frykatywność); b) cechy prozodyczne, przystugujace tylko segmentom fonologicznym stanowiacym ośrodek sylaby $i$ definiowalne poprzez odwołanie się do pojęcia sylaby (akcent, iloczas, ton).

Śrdwłac. distinctivus, z łac. distinctus 'różny, wydzielony' ${ }^{8}$

\footnotetext{
${ }^{8}$ Plański 1999, ss. 171-173
} 
2. Funkcja dystynktywna (diakrytyczna). Podstawowa funkcja dźwięków jęz. polegajaca na tym, że stuża one przede wszystkim do rozróżniania form jęz. (morfemów, wyrazów, zdań).

3. Cecha korelacyjna. Fonologiczna cecha dystynktywna, która różnia się fonemy tworzace pary korelacyjne (...), np. dźwięczność czy miękkość (palatalność) spółgłosek $w$ jęz. pol. ${ }^{10}$

4. Korelacja (...) $W$ praskiej szkole strukturalistycznej - zbiór wszystkich par fonemów, których człony każdej z nich różnia się tą samą cechą dystynktywna (...).

5. Korelacyjna para fonemów. W praskiej szkole strukturalistycznej 2 fonemy pozostające do siebie $w$ stosunku opozycji prywatnej, proporcjonalnej, jednowymiarowej (zob. Opozycja fonologiczna), np. w jęz. pol. $p: b, t: d, k: g, l u b$ $p: p$ ', $s: s^{\prime}, z: z^{\prime}$

$\mathrm{Z}$ definicji tych odczytujemy następujące fakty tyczące się fonologicznych cech dystynktywnych:

$>$ cechy te nazywane są synonimicznie jako „diakrytyczne”,

$>$ cechy te pełnią funkcję odróżniająca,

$>$ wśród cech tych wydzielamy cechy inherentne (definiowalne bez odwołania się do pojęcia sylaby) i (stojące w opozycji do nich) cechy prozodyczne (przysługujące tylko segmentom fonologicznym stanowiącym ośrodek sylaby i definiowalne poprzez odwołanie się do pojęcia sylaby),

$>$ analogicznie wśród cech dystynktywnych wydzielamy cechy korelacyjne (jest to taka cecha, która jako jedyna różnicuje dwa obiekty) i (w opozycji do nich) cechy niekorelacyjne.

W wyniku tych rozważań, ostatecznie otrzymuje my następujący schemat:

\footnotetext{
${ }^{9}$ Polański 1999, s. 186

${ }^{10}$ Polański 1999 , s. 82

${ }^{11}$ Polański 1999, s. 318

12 Polański 1999, s. 318
} 


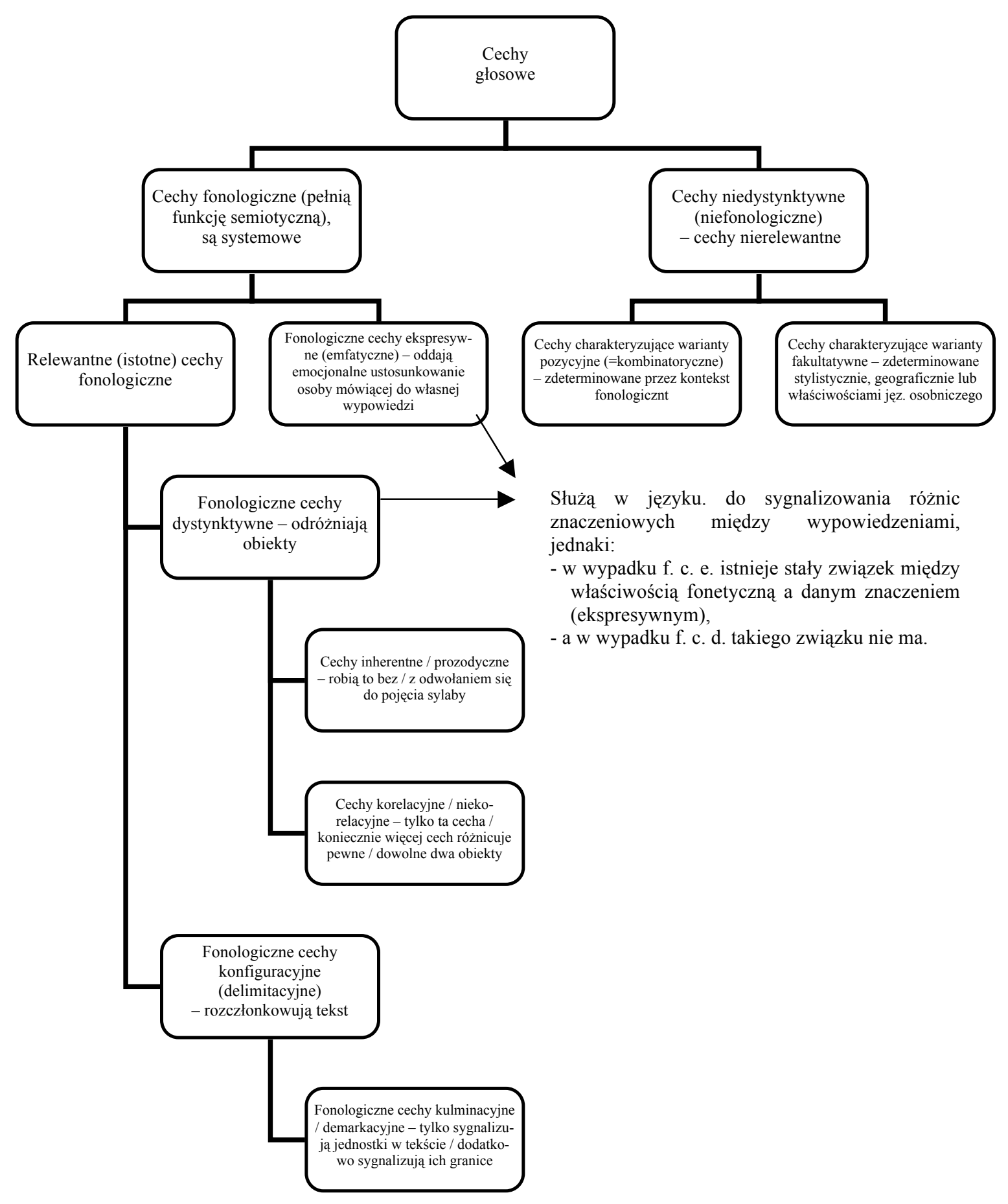

Schemat 7

\section{Wnioski}

Z podanego bezpośrednio powyżej diagramu możemy odczytać następujące, ważne dla nas - do opisu cech dystynktywnych - informacje: 
1. brak jest rozróżnienia między pojęciami „cechy dystynktywne” i „cechy diakrytyczne" 13 ,

2. cechy dystynktywne służą do odróżniania między sobą obiektów danego systemu (tu: fonologicznego),

3. owo odróżnianie może odbywać się z lub bez odwoływania się do pojęcia sylaby,

4. fonologiczne cechy dystynktywne są relewantne (istotne), a jako przynależne do tej kategorii - są również cechami systemowymi (własność przynależna cechom fonologicznym),

5. fonologiczne cechy dystynktywne (diakrytyczne) wraz z fonologicznymi cechami ekspresywnymi (emfatycznymi) służą $\mathrm{w}$ języku do sygnalizowania różnic znaczeniowych między wypowiedzeniami,

6. cechy niedystynktywne - to po prostu cechy niefonologiczne (niesystemowe), nierozróżnialne (a więc tożsame) $\mathrm{z}$ cechami nierelewantne (nieistotnymi); obrazowo można powiedzieć, że „być poza systemem” to po prostu „wypaść z gry” (stąd brak jest ich rozróżnienia),

7. cecha korelacyjna, to fonologiczna cecha dystynktywna, którą różnią się fonemy tworzące pary korelacyjne (tj. takie pary, które różnią się tą samą cechą dystynktywną); wyróżnienie tego typu cech spośród cech dystynktywnych jest jak najbardziej na miejscu - istnieją bowiem cechy, które nie są korelacyjne.

O miejscu cech dystynktywnych może świadczyć sytuowanie cech niedystynktywnych. $Z$ jednej strony określa się je jako niefonologiczne ( $z$ samej nazwy hasła „cechy niedystynktywne (niefonologiczne)"), a więc jako „niesystemowe”. Z drugiej zaś strony, w haśle „fonologia (fonemika, fonematyka)" ${ }^{14}$, czytamy:

Różnice fonetyczne, które w jednym jęz. są dystynktywne (fonologicznie relewantne (...)), w innych jęz. mogą być pozbawione funkcji dystynktywnej (mogą być fonologicznie nierelewantne lub mogą spełniać inną, niedystynktywną, funkcję fonologiczną, np. funkcję ekspresywna),

co rozszerza ich zakres na fonologiczne cechy ekspresywne (emfatyczne) i fonologiczne cechy delimitacyjne (konfiguracyjne).

\section{$4 \quad$ Wnioski}

Podsumowując możemy powiedzieć, że w konkretnym języku, cechy dystynktywne, to inaczej cechy istotne (inaczej: relewantne) i systemowe (tj. fonologiczne), a jako takie stałe i odporne (nieczułe, niewrażliwe) co do różnicowania znaczeń ze względu na własności czysto fonetyczne. Brak jest rozróżnienia między pojęciem „dystynktywny” i „diakrytyczny” (uznaje się je za równoważne), jak i między pojęciami „niedystynktywny” i „nierelewantny”. Same cechy dystynktywne dzieli się ze względu na zbiory odniesienia (na sylabiczne i niesylabiczne, czyli na prozodyczne i inherentne) oraz ze względu na ich siłę relacyjną (cechy wyróżniane ze względu na korelację).

\footnotetext{
${ }^{13}$ W pracy Lapis 2002, „dystynktywny” znaczy semantycznie rozróżniający, a „diakrytyczny” - syntaktycznie rozróżniający (poprzez nacechowaną cechę w literze - tzw. „ogonek”)

${ }^{14}$ Polański 1999, ss. 159-162
} 


\section{Bibliografia}

Jakobson, R. 1989. Pojęcie cech dystynktywnych w językoznawstwie; wspomnienia i rozważania, w: R. Jacobson $W$ poszukiwaniu istoty języka. Warszawa: Państwowy Instytut Wydawniczy ss. 217-256

Lapis, W. 2002. Rodzaje dystynkcji - analiza dystynktywnej roli znaków diakrytycznych w języku polskim. w: W. Krzemińska, P. Nowak (red.) Przestrzenie informacji. Poznań: Sorus ss. 109-118.

Polański, K. (red.) 1999. Encyklopedia Językoznawstwa Ogólnego. Wrocław: Zakład Narodowy im. Ossolińskich Wydawnictwo. 